\title{
Reflections
}

\section{R.I.P. Resilience}

\section{SILJE AURORA ANDRESEN}

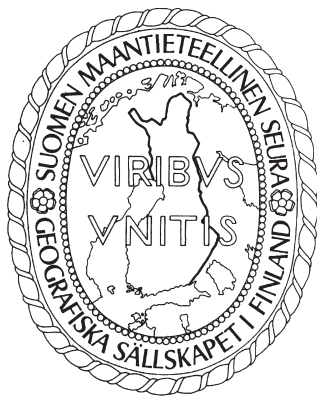

Andresen, S. A. (2019) R.I.P. Resilience. Fennia 197(1) 168-170. https://doi. org/10.11143/fennia.80093

Resilience was set to rest on 30 June 2016 in Trondheim, Norway. After a two-year quest for meaning, the concept now lies with its neoliberal supporters. Resilience and I first crossed paths at the beginning of my PhD journey in Geography. I was driven by curiosity and an eagerness to put resilience to use: after all, who doesn't want to be resilient? As the months passed by, I discovered the many different meanings the concept was associated with. Indeed, resilience refused to be put in a box. Yet, the concept contained some questions that I set out to try to answer in the "real" world. However, curiosity soon developed into frustration resilience revealed a rootlessness that was disturbing. Was it a means to measure? A means to conceptualize why some people make it and some do not? Or, was it in fact, just a means to get funding? Certainly, it was not a means to explain. Therefore, resilience will for me forever be remembered as an approach to enter and structure an interview guide, but now we must bid one another farewell. Your legacy will continue to live on in the neoliberal agenda.

Keywords: resilience, PhD crisis, neoliberal universities, passitivity

Silje Aurora Andresen, Department of Geography, NO-7491 Trondheim, Norwegian University of Science and Technology (NTNU), Norway. E-mail: silje.a.andresen@ntnu.no

R.I.P. Resilience. This paper is a personal account of my journey with the concept of resilience - from the beginning, where the somewhat naive idea was to qualitatively explore perceptions of resilience in a Norwegian context, to a midway PhD crisis. As the title suggests, I bid farewell to resilience after the crisis. To some degree, this paper is about why. More so, it is about the issues I became aware of during my journey with resilience: the first is how predetermined concepts in PhD or project announcements can lead to an expectation that you should deliver as you "promised" in your application. The second issue is the passitivity, meaning the acceptance of the use of problematic concepts because "we cannot escape them" within the university. I blame both issues on the neoliberal agenda that is seeping into the veins of universities causing a societal embolism. As has been pointed out in editorials in Fennia before (Kallio 2017; Kallio \& Riding 2018), the neoliberal agenda has reduced knowledge and dissemination to profit for market-driven publishing corporates, where the hours spent doing academic housekeeping (Lund 2018) is not even acknowledged.

This essay could be regarded as yet another self-absorbed piece on the challenges faced during a PhD journey. In that case, at least it could be considered therapeutic for me. On the other hand, I suspect that the issues might be recognizable, and hence spilling my guts may have value to others. To start from the beginning. I applied for a PhD position in Geography that was part of a project 
aiming to "assess resilience" in relation to climate change and natural hazards in Norway. Hence, in my project description I wrote that I wanted to "assess what resilience means, how it is acted upon in local communities, and what variations exist within and between different communities". My part was to contribute to a qualitative understanding of resilience; thus I began by trying to figure out how that could be done.

This proved challenging and not least, frustrating. Literature studies identified that "resilience continues to be mainly externally defined by expert knowledge from academia, international organizations and governmental agencies" (Weichselgartner \& Kelman 2015, 257). My idea was to respond to this shortcoming by conceptualizing resilience from the point of view of those who are at risk of experiencing hazards: the local communities. This could then be part of the proposed contribution from geography to the resilience research agenda: the consideration of context, space and time (Weichselgartner \& Kelman 2015). However, one dilemma I struggled with was how I, as part of academia, could theorize perceptions in a more just way for those who were the focus of my study without becoming part of what I was criticizing. I asked myself how and why we should legitimize conceptualizations that do not have roots in the people who ultimately experience them. I saw the need to contribute to policies that could be formed more intimately with those who are affected by them, and I had the ideal of working in a bottom-up rather than top-down fashion.

At this point, I set out to develop a critical resilience research agenda by including the normative and political ideals from political ecology. This, I argued, would better facilitate the inclusion of various actors and knowledges in disaster management policies. Hence, I broadly conceptualized resilience as a metaphor for how communities prepare for, act during and recover after a crisis (Norris et al. 2008). I found support in Rogers' (2015) argument that contextually sensitive frameworks together with highquality case studies, equally preoccupied with the positive potential of resilience as with the potential negative impacts, should guide resilience research. I figured that after fieldwork, the value of resilience would be clearer. Instead, fieldwork made the shortcomings of resilience even more haunting. Put bluntly, resilience explained nothing. After several attempts to reconcile a concept of resilience with the empirical material, I entered into a midway crisis.

It became clear to me that resilience, in a conceptual manner, did not work for my case study. It remained an abstract top-down expert conceptualization, unconnected to those facing and dealing with disasters on the ground. Furthermore, it did not make sense to explore the perceptions of resilience in a Norwegian context, as resilience [resiliens] was not a commonly used word in Norwegian. But most of all, it was its neoliberal connotation that bothered me. As argued by Chandler (2013), Evans and Reid (2014) and Tierney (2015), resilience accords well with a neoliberal agenda that individualizes challenges and responsibility. It facilitates the comfortable explanations of the causes and effects of crises for the elites: it is the individual's responsibility to be resilient, that is create opportunities from an inevitable unstable situation, rather than a structural responsibility that should be addressed. Hence, resilience effectively restricts a space of the political in which the neoliberal structures that create vulnerabilities can be contested.

Yet, resilience was the concept I had "promised" to use in my project description. Opportunely, during this period of the PhD journey I was also engaged in critical discussions concerning neoliberal developments in the university, where together with colleagues I took part in a minor "academic spring" (Andresen et al. 2015). During this awakening, I developed a strong sense of who I wanted to be as an academic and what values I stood by. Consequently, I reflected on what doing a PhD at the university entails today. Increasingly, PhD positions are tied to externally funded projects with predetermined concepts. The ripple effect of this is that you feel you have to deliver a product that complies with the concepts that secured money for the project. Like a consultant, you are hired to assess resilience or other taken-for-granted concepts. As a result, the idealistic pursuit of truth risks being swallowed by the instrumental production of knowledge.

At the time of my break up with resilience, it felt like I had wasted two years on something I could not make use of. This can be daunting when you have four years to complete a thesis. But I could not make myself continue with a concept the use of which I disagreed strongly with. This brings me to the second issue I encountered during my journey with resilience: passitivity within the university. Early career researchers, attempting to take a critical stand towards buzzword concepts, can be met by 
problematic statements that encourage passitivity. For example, I was told by a senior colleague that I should just stop brooding and go along with the pros and cons of resilience - I could not escape the "new wine" within disaster research. This statement came more out of passitivity than anything else: it is easier to just go along with something than to take an active stand against it.

This passitivity is killing the university as a true critical actor in society. To a large degree, this has to do with the neoliberal values that guide the practices of universities: being evaluated by publication points and the amount of external funding you bring in probably reduces people's ability to do anything else. We have become "individualistic and productive academic subjectivities" (Kallio \& Hyvärinen 2017, 121), chasing academic merit to the point where you do not even have time to critically question what you are obeying. To survive, you comply. Still, is not this compliance, or passitivity, a reason why the neoliberal agenda continues to prosper? It seems as though plenty of academics are not satisfied with the neoliberal cloak that turns them into capital. But nothing will change as long as passitivity is the chosen path. In 1946, Orwell reflected on how economic forces are threatening the independence of writers, but also, how the attacks on intellectual liberty come from within. As other Orwellian reflections of society, this unfortunately seems just as relevant today:

Everything in our age conspires to turn the writer, and every other kind of artist as well, into a minor official, working on themes handed to [him] from above and never telling what seems to him the whole of the truth. But in struggling against this fate he gets no help from his own side: that is, there is no large body of opinion which will assure him that he is in the right. (Orwell 2017, 131)

\section{Acknowledgements}

Thank you to Hilde Refstie, Silje Mathisen, Teklehaymanot G. Weldemichel and Michael Jones for believing in the idea and commenting on my drafts.

\section{References}

Andresen, S. A., Epremian, L., Jakobsen, T. S., Jones, M. \& Refstie, H. (2015) Fighting fog - the case of creeping neoliberalism and weakening university democracy in Norway. Krisis - Journal of Contemporary Philosophy 2 27-33.

Chandler, D. (2013) Resilience and the autotelic subject: toward a critique of the societalization of security. International Political Sociology 7(2) 210-226. https://doi.org/10.1111/ips.12018

Evans, B. \& Reid, J. (2014) Resilient Life: The Art of Living Dangerously. Polity Press, Cambridge.

Kallio, K. P. (2017) Subtle radical moves in scientific publishing. Fennia 195(1) 1-4. https://doi. org/10.11143/fennia.63678

Kallio, K. P. \& Hyvärinen, P. (2017) A question of time - or academic subjectivity? Fennia 195(2) 121124. https://doi.org/10.11143/fennia.67834

Kallio, K. P. \& Riding, J. (2018) Dialogical peer-review and non-profit open-access journal publishing: welcome to Fennia. Fennia 196(1) 4-8. https://doi.org/10.11143/fennia.70470

Lund, R. (2018) The social organisation of boasting in the neoliberal university. Gender and Education 1-20. https://doi.org/10.1080/09540253.2018.1482412

Norris, F. H., Stevens, S. P., Pfefferbaum, B., Wyche, K. F. \& Pfefferbaum, R. L. (2008) Community resilience as a metaphor, theory, set of capacities, and strategy for disaster readiness. American Journal of Community Psychology 41(1-2) 127-150. https://doi.org/10.1007/s10464-007-9156-6

Orwell, G. (2017) The prevention of literature (1946). In Milner, D. (comp.) Orwell on Truth, 130-140. Harvill Secker, London.

Rogers, P. (2015) Researching resilience: an agenda for change. Resilience 3(1) 55-71. https://doi.org/ $10.1080 / 21693293.2014 .988914$

Tierney, K. (2015) Resilience and the neoliberal project: discourses, critiques, practices - and Katrina. American Behavioral Scientist 59(10) 1327-1342. https://doi.org/10.1177/0002764215591187

Weichselgartner, J. \& Kelman, I. (2015) Geographies of resilience: challenges and opportunities of a descriptive concept. Progress in Human Geography 39(3) 249-267. https://doi. org/10.1177/0309132513518834 